always parallel the strike of the cleavage". Here, and also in the introduction to the stereographic projection method, the value of plunge determinations and their utility might well be elaborated, using the results of Wegmann's work in Finland as a guide and in further illustration. Moreover, it may be remarked that for Lugeon and Argand a nappe is not necessarily based on a thrust; according to Argand, who knew the ground much more intimately than any critic, the reversed limb of the Dent Blanche nappe, though greatly thinned, is never cut out (cf. p. 119). Reference to the Alps suggests the question whether, in a book on structural geology, the Alps should be dismissed in twenty-nine lines while, for example, submarine valleys receive nearly 130 .

In the introduction the importance of discrimination between fact and hypothesis is emphasized. Structures can be seen and measured; movernents can often be inferred; but knowledge of the active forces is rarely more than hypothetical. Yet the author, very surprisingly, proposes (pp. 48-49) that structural terms should have genetic significance. This implied confusion between description and interpretation is perhaps responsible for his difficulty with over-and under-thrusting (p. 128). Taken as a whole, the standard of the new edition marks a real advance in the presentation of an admittedly difficult subject. A few criticisms have been made, but they are intended to be constructive, and they are offered in the hope that in future editions this excellent book may yet become the leader in its class.

\section{Early Man}

\section{EVOLUTION OF MAN}

A Survey of Human Origins. By Alan Houghton Brodrick. Pp. $288+13$ plates. (London: Hutchinson's Scientific and Technical Publications, 1948.) $18 s$. net.

D OPULAR expositions on the subject of early man can roughly be divided into two categories : those of the journalistic type which are little more than dramatized versions of more authoritative accounts, 'written down' for the apparently unintelligent reader ; and those which strive to be sober and critical surveys based on a careful study of scientific documents, and, in some cases, of the original evidence. Mr. A. H. Brodrick's book finds its place in the latter category. The author weighs the available evidence (much of it still very meagre) with due care, and presents his conclusions with commendable restraint. Clearly his book is intended for the intelligent reader. But this is not to say that it is written in an unattractively pedagogic style; on the contrary, the story of discovery is presented in the form of a stimulating narrative which flows easily from one item to another, and which conveys (in brief) a vivid impression of the whole field of palwo-anthropolugy as it stands to-day.

During the past fifteen years or so, discoveries relating to early man have been most remarkable for their abundance; it is therefore very appropriate that a book of this sort should be available which brings the story of human evolution up to date for the general reader. This the author does very effectively, and in his book references will be found to a number of significant discoveries which otherwise have not yet found their way into popular accounts of human evolution. Among such novel features are descriptions and discussions of the Neanderthal remains found in Italy, the palæolithic cave paintings at Lascaux, the relics of Pithecanthropus and allied forms found by Dr. von Koenigswald in Java shortly before the Second World War, the Acheulean site at Olorgesailie in Kenya, palæolithic industries in Asia, the Australopithecine fossils of South Africa, the Swanscombe skull fragments, and the neanderthaloid skeleton from Uzbekistan.

But new discoveries proceed apace, and even since this book was published in 1948, still more new finds of great significance have been made. Therefore, since Mr. Broderick's book is, without doubt, one of the best popular expositions of early man now available, it is to be hoped that a new edition will not be long forthcoming.

\section{A HISTORY OF SCIENCE}

\section{Science, Past and Present}

By Dr. F. Sherwood Taylor. New edition. Pp. x+ $368+28$ plates. (London: William Heinemann, Ltd., 1949.) 12s. 6d. net.

W ${ }^{\mathrm{E}}$ welcome this new edition of the work of the keeper of the Museum of the History of Science in Oxford. Dr. F. Sherwood Taylor's "Science, Past and Present" was first published in 1945 and was immediately reprinted. It is appropriate that it should now be presented in a larger edition and produced in a style worthy of its contents.

The book, in simple yet scientific language, depicts science as a living, growing organism and thereby demonstrates its powers and limitations, and so sets it in its place among the various activities of man. kind. Dr. Taylor has in mind the needs of the intelligent layman, the 'sixth form' and the science specialist who wishes to see the place of his limited study in a greater scheme of things. It is pleasing to note that this book is entirely free from the political prejudices and propaganda which mar so many works which deal with the history and social applications of science.

The story of mechanics, physics and chemistry, biology and geology, which is the 'stock in trade' of most writers on the history of science, is enriched by the addition of an account of the development of other parallel studies such as public health, the methods of science and its functions. The author faces the problems of the limitations of science. "Those who remember that scientific laws are sum. maries of observations and not legal enactments will have no difficulty in discovering the phenomena to which they can safely be applied." One recalls the lines of the poet Walt Whitman in speaking of scientific men :

"Gentlemen! to you the first honours always :

Your facts are useful and real--and yet they are not my dwelling ;

(I but enter by them to an area of my dwelling.)"

One of the most useful features of Dr. Sherwood Taylor's book is the way in which he supports each chapter with a set of extracts from contemporary scientific documents. Such material is not easily available in sufficient quantity, and the work under review is a valuable additional source. It remains to be said that there is a good bibliography, that the pictures and diagrams are of first-rate quality and that the book is beautifully produced.

W. L. SUMNER 